\section{Science Masters' Association}

THE annual meeting of the Science Mastors' Association is to be held in University College, Gower Street, London, W.C.1, during December 30-January 2. The programme includes the following lectures: "The Scope of Modern Physics", by Prof. H. S. W. Massey ; "Principles of Organic Chemistry", by Prof. E. D. Hughes; "Algal Pigments", by Dr. G. E. Fogg; "Industrial Applications of Radioisotopes", by J. L. Putman; "Learning in Octopuses", by Prof. J. Z. Young; "Opportunities for Students in Colleges of Technology", by Dr. J. Topping; "Old Metals and New Valencies: the Stabilization of Unusual Valency States", by Prof. R. S. Nyholm; "Techniques in Nuclear Physics", by Dr. E. H. S. Burhop; "New Engineering Problems in Aeronautics", by H. G. Conway ; "The Study of Ripples by the Schlieren Method", by W. Llowarch ; "Molecular Spectra and Molecular Structure", by Dr. D. J. Millen; "Some Problems in Teaching Science in Large Secondary Schools", by R. J. Scammell. Accommodation for members at the meeting will be provided at Queen Elizabeth College, Kensington, W.8 ; Canterbury Hall and Bentham Hall, both in Cartwright Gardens, W.C.1. Further information can be obtained from the annual meeting secretary, Mr. W. H. Dowland, 93 Westbourne Road, West Hartlepool, Co. Durham.

Imperial Chemical Industries Transfer Scholarships

LAST year, thirty-three university students who decided that they wanted to change from the arts to science were able to do so by taking advantage of the Imperial Chemical Industries transfer scholarship scheme. Most of these students have now passed their examinations and have entered their chosen science honours school. Of the twenty-seven transfer scholars elected in 1956, more than 80 per cent successfully made the change from arts to science. These encouraging figures have persuaded Imperial Chemical Industries to extend its guarantee of scholarship funds for a further two years to the universities which originally co-operated in the scheme. These are Oxford, Cambridge, Liverpool, Imperial College of Science and Technology, London, and King's College, Newcastle. At Oxford the number of scholarships available will be extended so that, in common with Cambridge, every college will have a transfer scholarship in its gift. Scholarships not taken up can be passed on to other colleges which have more than one suitable candidate. In all, sixtyfive of these scholarships are now available, the universities co-operating also including Birmingham, Bristol and Sheffield, which came into the scheme a little later.

\section{University News :}

Belfast

THE following appointments have recently been made : Dr. C. L. Wilson, to a personal chair in analytical chemistry; Dr. R. B. Welbourn, to a personal chair in surgical science; Dr. P. J. B. Clarricoats, to a lectureship in light electrical engineering; Dr. P. C. Elmes, to a lectureship in therapeutics and pharmacology.

London

THE following have been appointed to University readerships in the subjects indicated: Mr. J. R. D. Francis, lecturer at the Imperial College of Science and Technology (fluid mechanics); Dr. R. W. Tiffen, lecturer at Birkbeck Colloge (applied mathe- matics) ; Mr. W. J. Tulley, lecturer at Guy's Hospital Medical School (orthodontics). Dr. Emrys Jones, lecturer in geography at the Queen's University of Belfast, has been appointed to the University readership in social geography tenable at the London School of Economics and Political Science.

\section{Announcements}

The Christmas Lecture arranged by the Institution of Electrical Engineers will be held in the Institution's rooms on December 31 , at 3 p.m., when Dr. E. R. Laithwaite (University of Manchester) will speak on "Invention and New Machines". Admission to the Lecture is by ticket, obtainable, free of charge, from the Secretary, Institution of Electrical Engineers, Savoy Place, London, W.C.2.

The annual Christmas lectures organized by the Royal Photographic Society for a juvenile audience, which will be given in the Department of Photography at the Regent Street Polytechnic, London, W.1, at 2.30 p.m. on January 1 and 2,1959 , will be on "Picture Making in Photography". Tickets are free, and can be obtained on application to the Secretary of the Royal Photographic Society, 16 Princes Gate, London, S.W.7.

THe annual conference of the Geographical Association will be held in the London School of Economics, Houghton Street, London, W.C.2, during December 30, 1958-January 2, 1959. Further details can be obtained from the honorary conference organizer, Mr. R. C. Honeybone, University of London Institute of Education, Malet Street, London, W.C.1.

THE Palæontology Association will hold a discussion meeting on "Micro-palæontology" in the Department of Geology, Sedgwick Museum, Cambridge, on December 12 and 13. Sixteen papers on spores, ostracods, conodonts and foraminifera will be read, and there will also be a large number of exhibits. Further information can be obtained from Dr. Gwyn Thomas, Department of Geology, Imperial College of Science and Technology, London, S.W.7.

THE Physical Society is organizing conference on "Problems of Collective Motion", to be held at the University of Birmingham, on January 2 and 3, 1959. Informal discussions will follow introductory talks on gaseous plasma; plasma problems in the electron theory of metals; liquid helium and superconductivity; and collective problems in nuclear dynamics. The conference is open to non-members of the Physical Society on payment of a fee of one guinea. Further information can be obtained from Miss E. Mills, Physical Society, 1 Lowther Gardens, Prince Consort Road, London, S.W.7.

THe following scholarships will be offered by the Institution of Naval Architects for competition in 1959 : Denny Scholarships in Naval Architecture and Naval Engineering: $£ 175$ per annum, tenable for four years at the University of Glasgow, and open to British subjects less than nineteen years of age who have not yet begun an apprenticeship, or served not. more than one year of it with Messrs. William Denny \& Bros., Dumbarton. Parsons Scholarship in Marine Engineering: $£ 175$ per annum, open to British apprentices or pupils in marine engine works or the Royal Dockyards less than twenty-one years of age. Yarrow Scholarship in Marine Engineering : conditions as for Parsons Scholarship in Marine Engineering. Further particulars can be obtained from the Secretary, Institution of Naval Architects, 10 Uppor Belgrave Street, London, S.W.1. 